NBER WORKING PAPER SERIES

FINANCIAL SOPHISTICATION IN THE OLDER POPULATION

\author{
Annamaria Lusardi \\ Olivia S. Mitchell \\ Vilsa Curto \\ Working Paper 17863 \\ http://www.nber.org/papers/w17863 \\ NATIONAL BUREAU OF ECONOMIC RESEARCH \\ 1050 Massachusetts Avenue \\ Cambridge, MA 02138 \\ February 2012
}

The research reported herein was conducted pursuant to grants from the U.S. Social Security Administration (SSA) to the Financial Literacy Center and the Michigan Retirement Research Center funded via the Financial Literacy Research Consortium and the Retirement Research Consortium. Additional support was provided by the Pension Research Council and Boettner Center at the Wharton School of the University of Pennsylvania, and the FINRA Investor Education Foundation. We are grateful to Richard Derrig for sharing his PRIDIT code. Opinions and errors are solely those of the authors and not of the institutions with which the authors are affiliated The views expressed herein are those of the authors and do not necessarily reflect the views of the National Bureau of Economic Research.

At least one co-author has disclosed a financial relationship of potential relevance for this research. Further information is available online at http://www.nber.org/papers/w17863.ack

NBER working papers are circulated for discussion and comment purposes. They have not been peerreviewed or been subject to the review by the NBER Board of Directors that accompanies official NBER publications.

(C) 2012 by Annamaria Lusardi, Olivia S. Mitchell, and Vilsa Curto. All rights reserved. Short sections of text, not to exceed two paragraphs, may be quoted without explicit permission provided that full credit, including $\odot$ notice, is given to the source. 
Financial Sophistication in the Older Population

Annamaria Lusardi, Olivia S. Mitchell, and Vilsa Curto

NBER Working Paper No. 17863

February 2012

JEL No. D91,G11,J14,J18

\section{ABSTRACT}

This paper examines data on financial sophistication among the U.S. older population, using a special-purpose module implemented in the Health and Retirement Study. We show that financial sophistication is deficient for older respondents (aged 55+). Specifically, many in this group lack a basic grasp of asset pricing, risk diversification, portfolio choice, and investment fees. Subpopulations with particular deficits include women, the least educated, persons over the age of 75, and non-Whites. In view of the fact that people are increasingly being asked to take on responsibility for their own retirement security, such lack of knowledge can have serious implications.

Annamaria Lusardi

The George Washington University

School of Business

2201 G Street, NW

Duques Hall, Suite 450E

Washington, DC 20052

and NBER

alusardi@gwu.edu

Olivia S. Mitchell

University of Pennsylvania

Wharton School

3620 Locust Walk, St 3000 SH-DH

Philadelphia, PA 19104-6302

and NBER

mitchelo@wharton.upenn.edu
Vilsa Curto

Stanford University

Department of Economics

579 Serra Mall

Stanford, CA 94305

vcurto@stanford.edu 


\title{
Financial Literacy and Financial Sophistication in the Older Population
}

\author{
Annamaria Lusardi, Olivia S. Mitchell, and Vilsa Curto
}

Americans are increasingly likely to hold individual retirement accounts such as IRAs or 401(k) plans, accumulate privately-held assets, and/or hold debt, meaning that most people will need a certain amount of financial sophistication to be able to manage assets and debts sensibly over their lifetimes. Yet financial literacy in the general public is disturbingly low. For instance, only half of age 55+ respondents in the United States surveyed in a special module of the 2004 Health and Retirement Study (HRS) could correctly answer two simple questions regarding inflation and compound interest. Only one-third correctly answered these two questions as well as a third question about risk diversification (Lusardi and Mitchell, 2008, 2011b). Evidence of low numeracy and low financial sophistication is also evident for younger respondents in surveys including the Rand American Life Panel (ALP) and the Survey of Consumers (Hilgert, Hogarth and Beverly, 2003; Lusardi and Mitchell, 2009; Lusardi, Mitchell and Curto, 2010). Moreover, financial illiteracy is particularly acute among particular subgroups including women, minorities, and those with low income and education (Lusardi and Mitchell, 2007, 2008). And consumer financial illiteracy can have important consequences: for instance, those who lack literacy are much less likely to plan for retirement (Lusardi and Mitchell, 2007, 2009, 2011a, 2011b); are more likely to end up with little wealth close to retirement (Lusardi and Mitchell, 2007); are less likely to invest in stocks (Kimball and Shumway, 2006; van Rooij, Lusardi and Alessie, 2011; Yoong, 2011); and tend to use high-cost borrowing channels (Lusardi and Tufano, 2009a). Moreover, more literate individuals are more likely to choose mutual funds with lower fees (Hastings and Tejeda-Ashton, 2008; Hastings and Mitchell, 2011). 
Our paper analyzes new data from the HRS on financial sophistication among the older American population, specifically persons over the age of $55 .{ }^{1}$ While prior studies have examined measures of basic financial literacy, they have not considered financial sophistication. Accordingly, the present research is informative in three important ways. First, our findings can be used to help design financial education programs that are more effective in fostering saving and informing investment choice. By examining knowledge about the behavior of the stock market, basic asset pricing, and the importance of mutual fund fees on long-term investments, explicit suggestions can be provided regarding topics that can usefully be covered in financial education programs. Second, this paper identifies which older population subgroups are most likely to be financially unsophisticated and thus potentially be most prone to poor financial decision-making. Third, our paper makes a methodological contribution by examining alternative ways to combine answers to financial literacy questions into an overall index, to help identify which particular questions are most important in predicting financial literacy.

\section{Building on previous research}

Older Americans are not particularly financially literate. Lusardi and Mitchell (2011b) use the 2004 HRS to establish this pattern among older individuals, and Lusardi and Mitchell (2007) replicate these findings for Early Baby Boomers, who display not only low numeracy but also a lack of knowledge of fundamental economic concepts such as interest compounding. Moreover, particular sub-groups of the population suffer even greater deficits in financial literacy. For instance, women display much lower literacy than men and are much less likely to plan for retirement (Lusardi and Mitchell, 2008, 2011d). Furthermore, minorities and those with

\footnotetext{
${ }^{1}$ This module was designed by the authors of this paper in collaboration with Miles Kimball and Tyler Shumway.
} 
low education and low income are far less financially knowledgeable (Lusardi and Mitchell, 2007; Smith and Stewart, 2008).

These results are troublesome, given the increasing complexity of financial instruments and the many transactions households must undertake that require sound economic understanding. For instance, Moore (2003) found that mortgage borrowers in Washington State knew little about compound interest and were confused about the terms of their mortgages. Campbell (2006) noted that many households failed to refinance their mortgages over the 20012003 period when interest rates were falling. Furthermore, financial illiteracy can have significant long-term financial consequences. For example, those who underestimate the power of interest compounding are more likely to end up with excessive amounts of debt (Lusardi, 2009; Lusardi and Tufano, 2009a). Homeowners who fail to refinance or to correctly estimate the amount by which interest rates could change will pay significantly more in mortgage interest (Campbell, 2006).

Most of the financial literacy studies mentioned above draw on evidence gathered in the short 2004 HRS experimental module by Lusardi and Mitchell. Those questions have been used very successfully to explore the links between financial literacy and retirement planning as well as retirement wealth accumulation. ${ }^{2}$ Nevertheless, that module included only three questions designed to assess basic numeracy and knowledge of basic economic concepts such as inflation and risk diversification. For this reason, we have now expanded our investigation into financial knowledge among the older population by asking additional questions which have been added to other surveys. For instance, we developed questions on financial knowledge for the American Life Panel, which we first piloted on the Dutch DNB Household Survey (Lusardi and Mitchell,

2 These questions have also been fielded in related surveys in Germany, Italy, the Netherlands, Sweden, Russia, New Zealand, and Japan, and results reveal similar patterns of widespread illiteracy (see Lusardi and Mitchell, 2011c for an overview). 
2009; van Rooij, Lusardi and Alessie, 2011). These new measures cover not only basic but also sophisticated financial knowledge, eliciting knowledge on the difference between bonds and stocks, the working of the stock market, and basic asset pricing. This expanded set of evidence on financial knowledge in turn influenced the wording of the new 2008 HRS module, to be described in more detail below. Using this extended information, we can now better classify respondents in terms of financial sophistication and address specific knowledge lacunae.

Measuring financial sophistication entails asking about concepts that respondents may not find familiar. For this reason, we find it useful to present respondents with alternative question wordings, so as to assess whether they understand the questions posed; in this case, respondents are randomly assigned to one of two sets of alternative question wordings. As an example, one set of respondents is asked whether the following statement is true or false: 'If you invest for the long run, the annual fees of mutual funds are important'; while the second group is asked: 'If you invest for the long run, the annual fees of mutual funds are unimportant.' Such wording reversals permit us to investigate the extent of measurement error in responses to the financial sophistication questions, an important methodological innovation. ${ }^{3}$ In general, when people are financially unsophisticated, it proves difficult to elicit accurate responses to unfamiliar concepts. This procedure allows researchers to evaluate how much respondents understand the questions that were posed to them and also the extent of guessing and lack of knowledge.

In what follows, we first describe our data and methodology, and then we summarize findings of most interest. A final section offers conclusions and policy implications.

\footnotetext{
${ }^{3}$ Both the Dutch DNB Household Survey and the American Life Panel used a related approach for a small subset of the questions, and there the wording of the questions did matter, particularly for questions measuring financial sophistication (Lusardi and Mitchell, 2009; van Rooij, Lusardi and Alessie, 2011).
} 


\section{Data and methodology}

In 2008, we subjected around 1,000 randomly-selected HRS respondents in the United States to a special module of questions assessing knowledge of the stock market and asset prices, investment strategies, risk diversification, the importance of fees, and related topics. Respondents averaged age 67, with about half (55\%) female. Some 15\% had less than a high school education, $32 \%$ had completed high school, $24 \%$ had some college, and $28 \%$ had college or advanced degrees. Most (81\%) of the respondents were White, with 9\% African-American, and 8\% Hispanic (see the Appendix Table for descriptive statistics). ${ }^{4}$

The 10 questions of key interest here are grouped into four categories, according to the topic they cover: knowledge of capital markets, risk diversification, knowledge of fees, and savvy/numeracy (see Table 1). Next we report the specific language used in the questions employed for our analysis; in each case with the answer a sophisticated individual would indicate as true provided in bold:

\section{Knowledge of capital markets}

(1) An employee of a company with publicly traded stock should have [a lot / little or none] of his or her retirement savings in the company's stock.

\section{Sophisticated investor: little or none}

(2) (Please indicate whether you think each statement is true or false. If you are not sure, give your best guess.) If the interest rate falls, bond prices will [rise/fall].

\section{Sophisticated investor: rise}

(3) (Please indicate whether you think each statement is true or false. If you are not sure, give your best guess.) [If/Even if] you are smart, it is [easy/hard] to pick individual company stocks that will have better than average returns.

\section{Sophisticated investor: Even if/hard}

\section{Risk diversification}

(4) (Please indicate whether you think each statement is true or false. If you are not sure, give your best guess.) You should invest [most of your money in a few good stocks that you

\footnotetext{
${ }^{4}$ For more information on this dataset see http://hrsonline.isr.umich.edu/
} 
select rather than in lots of stocks or in mutual funds/ in either mutual funds or a large number of different stocks instead of just a few stocks].

Sophisticated investor: most of your money in a mutual funds or a large number of stocks...

(5) When an investor spreads money between 20 stocks, rather than 2, the risk of losing a lot of money [decreases/increases].

Sophisticated investor: decreases

\section{Knowledge of fees}

(6) If you invest for the long run, the annual fees of mutual funds are [unimportant /important].

Sophisticated investor: important

(7) It is [hard/easy] to find mutual funds that have annual fees of less than one percent of assets.

Sophisticated investor: easy

\section{Savvy/numeracy}

(8) To make money in the stock market, you [should not/have to] buy and sell stocks [too often.]

Sophisticated investor: should not

(9) Using money in a bank savings account to pay off credit card debt is usually a [good/bad] idea.

Sophisticated investor: good

(10) If you start out with $\$ 1,000$ and earn an average return of $10 \%$ per year for 30 years, after compounding, the initial $\$ 1,000$ will have grown to [more/less] than $\$ 6,000$.

Sophisticated investor: more $^{5}$

Table 1 here

Knowledge of capital markets:

Recalling that this module was fielded in the midst of the volatile capital market of 2008, it is particularly interesting to see how much respondents knew about key financial concepts. The evidence in Table 1 supports the conclusion that older Americans displayed a deep lack of understanding about key concepts related to risk diversification, bond prices, and portfolio choice. For instance, many respondents expressed a support for holding own employer company

\footnotetext{
${ }^{5}$ For all of these questions, it is also possible to answer with "do not know" or refuse to answer.
} 
stock, despite the fact that it is unlikely to be wise to hold much own employer stock from a risk diversification viewpoint. ${ }^{6}$ We also find it of interest that answers are sensitive to how the questions are phrased. Respondents given the first wording of this question (an employee of a company with publicly traded stock should have a lot of his retirement saving in that company's stock) state that holding a lot of company stock is not a good idea. Yet when presented with the reverse wording, most reject the proposal to hold little or no money in company stock. This discrepancy suggests that the question was not fully understood, perhaps because of the use of financial terminology (for example one has to know what a publicly traded stock is).

A large majority of respondents (60\%) also did not know about asset pricing, which we explore by asking whether people knew about the inverse relationship between bond prices and interest rates. This is a particularly good question to assess financial sophistication because it is difficult (if not impossible) to know or infer the correct answer to this question without having some knowledge of finance. When we piloted this question in both the ALP and the Dutch DNB, we found that few (always under one-half) of those respondents knew about bond pricing; there the wording order of the question influenced answers. Both conclusions are also true for the U.S. population. When presented with the statement 'If the interest rate falls, bond prices will fall' (second wording), only about one-third (35.7\%) of respondents answered correctly; when the wording was reversed (first wording: 'If the interest rate falls, bond prices will rise'), more answer correctly (44.7\%) and this difference is statistically significant. The low fraction of financially sophisticated respondents is consistent with the U.S. 2009 Financial Capability Study

\footnotetext{
${ }^{6}$ This is because the typical US worker will have a large part of his total wealth in human capital, so that labor earnings will be highly correlated with his employer's financial stability. For a discussion of the pros and cons of employer stock, see Benartzi, Thaler, Utkus, and Sunstein (2004) and Ruffino (2011).
} 
where knowledge about asset pricing was shown to be low among older as well as younger respondents (Lusardi, 2011).

Many respondents were aware that 'Even if one is smart, it is very difficult to pick individual stocks that will have better than average returns.' But here, too, responses varied depending on how the question was asked: in one case $73.7 \%$ got the correct answer, but only $37.6 \%$ got it correct using the reverse ordering. In other words, this question, too, was poorly understood by respondents.

Knowledge of risk diversification:

Knowledge of risk diversification is very important when contemplating investment options. Table 1 indicates that almost two-thirds of respondents knew that 'it is not a good idea to invest in a few stocks rather than in many stocks or in mutual funds,' which might be thought to imply some sophistication about risk. Yet this question jointly tests knowledge of risk diversification and awareness of mutual funds, as indicated by results when we reversed the question wording: responses proved quite sensitive. The second risk question sought to avoid this by simplifying the question and using less financial terminology; and now we find that most knew that spreading money across 20 stocks rather than two decreased the risk of losing money (and here, word order did not matter). We hypothesize that some of the sensitivity regarding question wording may be due to the use of financial terminology. For instance, many respondents might not have known what a mutual fund is, or the fact that mutual funds invest in a pool of stocks.

Knowledge of fees:

Two of the module questions sought to assess peoples' knowledge of investment fees (see Table 1), an important topic since higher fees erode retirement wealth. And several prior studies have found that investors often overlook fees when deciding how to invest (Mitchell, Todd and Bravo, 
2008; Choi, Laibson and Madrian, 2010). In our sample of older Americans, around two-thirds seemed to know that mutual fund fees are important when investing for the long run. Nonetheless, responses were again sensitive to question wording, perhaps due to the fact that respondents needed to know both about mutual funds and investing for the long run. Additionally, a large majority of respondents said they would find it difficult to locate mutual funds charging annual fees of less than one percent of assets, suggesting that many respondents may not know about low-cost mutual funds. The fact that again there is some sensitivity to question wording confirms that, here too, respondents have difficulty with financial terminology (fees, mutual funds, etc.).

Savvy/numeracy:

While it is important to evaluate whether people understand fees, it is also important to know if they can do something to reduce the fees they pay. Table 1 shows what our HRS respondents knew regarding the question of whether 'To make money in the market they should not buy and sell stocks too often.' Most respondents (over 60\%) were savvy regarding stock churning, and there is little sensitivity to wording order for this question. We also explore other financial behaviors along with day-to-day financial management such as dealing with credit cards. Most of the older respondents knew that using money in a bank account to pay off credit card debt is usually a good idea, and responses were not particularly sensitive to question wording, probably due to the simplicity of the question. By contrast, the query assessing whether people knew about interest compounding and whether they could do complex calculations involving interest rates were more difficult. More than $60 \%$ could figure out that an initial investment of $\$ 1,000$ would grow more than six-fold when invested at an interest rate of $10 \%$ for 30 years, but the alternative wording generated different answers so at least some were guessing. 


\section{Financial Literacy Indexes:}

While these questions all measure knowledge required for financial decision-making, one might also be interested in a summary measure or index across all questions so as to categorize respondents as relatively more or less sophisticated. One approach would simply compute the fraction of all questions answered correctly. We compute this value and subtract it from the variable mean and divide by ten, such that it is now centered on zero (with a standard deviation of 0.2). Yet a disadvantage of this approach is that this score weights each question equally, even though in Table 1, it is clear that some questions are much harder for people to answer correctly than others.

For this reason we also develop a second, more sophisticated, index which relies on a weighting scheme which takes into consideration the relative difficulty of each question. Specifically we employ a weighted scoring mechanism called PRIDIT designed to deal with difficult-to-observe outcomes with indicator variables that proxy for the dependent variable that are binary or categorical. ${ }^{7}$ Moreover, the PRIDIT approach is a scoring mechanism that allows us to construct an index that weights questions according to how difficult and how informative they are. The index is constructed in two steps. In the first step, each individual's response to a given question is rescaled according to how many people answered that question correctly. That is, PRIDIT applies a negative penalty for a question that is answered incorrectly, and the penalty is greater when a larger proportion of the sample answered the question correctly. Similarly, the procedure gives more credit for a correct response to a question that few people answered correctly. In the second step, principal components analysis is used to analyze the rescaled

\footnotetext{
${ }^{7}$ This approach was devised by Brockett et al. (2002) who use it to assess insurance fraud, where investigators use several indicator variables (such as whether an individual had time gaps between medical treatments or experienced many hospital visits) to assess whether a given claim might be fraudulent. This approach has recently been used to measure financial literacy in Chile (see Behrman et al., 2012).
} 
responses, which allows us to take into account the amount of correlation across questions. ${ }^{8}$ Weights are computed from the principal components analysis so that questions that are less correlated with a linear combination of the other questions are given more weight because they are more informative. The mean of this variable is also zero (and standard deviation of 0.03 ).

For this dataset, we also find that the PRIDIT measure and the simple index prove to be highly correlated, at 0.977 . In other words, we anticipate that both measures will do a reasonably good job in capturing the variation in financial literacy measured with our questions. Yet the PRIDIT model tells us which questions are most informative about overall financial sophistication levels. Interestingly, questions $4,5,8$, and 10 are the most informative; these are related to knowledge of risk diversification, financial savvy, and numeracy. We interpret these results to mean that if one were to design a survey aimed at measuring financial literacy, it would be most useful to ask questions assessing knowledge of these topics.

Figure 1 here

\section{Analyzing financial sophistication: Who knows the least?}

In this section we look more deeply at how financial sophistication is distributed across the older population. Table 2 reports results using as a dependent variable the simple index, and Table 3 uses the PRIDIT index.

Tables 2 and 3 here

Both sets of results confirm the importance of sex differences in financial sophistication. That is, irrespective of which index is used, women consistently know less than men (column 1)

\footnotetext{
${ }^{8}$ More precisely, we calculate the principal components and use the principal component vector with the largest corresponding eigenvalue. This principal component vector captures more variance in the data than any of the other eigenvectors. We then use this vector to compute the PRIDIT weights that are then used to construct the PRIDIT index.
} 
and the result persists after controlling for education, age, and race/ethnicity (column 5). This has been reported in prior surveys, regardless of whether one looks at just the basic versus sophisticated knowledge (Lusardi and Mitchell, 2008; Lusardi and Tufano, 2009a,b). ${ }^{9}$

Both Tables also confirm that more educated people are better informed, with those having a college or higher degree having the greatest advantage compared to the reference case, high school dropouts. The same phenomenon is clear from column 6 in both tables, where other controls are included. This extends prior results on basic financial literacy measures provided by Lusardi and Mitchell (2007; 2011b). Race/ethnicity factors also play a role. Specifically, African-American and Hispanic respondents have lower measured levels of financial sophistication than do their White counterparts, the reference group (column 3). Relatively speaking, Hispanics suffer a larger disadvantage than do Blacks, extending our findings from prior waves of the HRS that measure basic financial knowledge (Hilgert et al., 2003; Moore, 2005; Lusardi and Tufano, 2009a,b; Lusardi and Mitchell, 2011b; ). Again, the results are robust to other controls in column 5 .

The effect of aging on financial sophistication is most strongly negative for those aged 75+, with no measurable differences in column 4 for those aged 65-74 versus their younger reference group (aged 55-65). A similar pattern emerges from column 5, when other factors are controlled in the multivariate regression. While we cannot differentiate between age and cohort effects using this single cross-section dataset, we did find similar results when examining earlier HRS waves (in 2004) using simpler measures of financial literacy (Lusardi and Mitchell, 2011b). Evidently both basic and sophisticated knowledge falls with age.

\footnotetext{
${ }^{9}$ This is true not just in the United States, but also in many other nations as well; see Christelis, Jappelli and Padula (2010) and Lusardi and Mitchell (2011c).
} 
As noted previously, it is also useful to examine whether and how responses varied according to the order in which the question wording was provided. In Tables 2 and 3, we examine these patterns in two different ways. Column 6 adds a simple dummy variable to the model indicating which wording each respondent received. Evidently the patterns of financial sophistication documented earlier are not attenuated; if anything, they become stronger. Columns 7 and 7 ' in both tables interact the wording dummy with all other variables, to check for differential sensitivity by group. Our results show that only one subgroup is strongly affected by the order of the question wording: women. In particular, when women were shown the first wording, they were more likely to score better on both simple and PRIDIT sophistication indexes, holding constant other factors.

Tables 4A and 4B permit us to explore in more detail exactly which wording induced the HRS women to be more likely to answer questions correctly. Table 4A examines differences by sex in the mean percentage of 'do not know' responses for each of the survey questions; we report p-values for the statistical significance of the mean differences. Table 4B uses as the dependent variable a tally of the number of 'do not know' responses for the outcome variable (we have also subtracted the mean and divided by 10 as before). We then show three specifications that are identical to the columns 6 and 7+7' in tables 2 and 3 . Two important conclusions emerge from this analysis. First, women were far more likely to answer 'do not know' across the board; in many cases they were approximately twice as likely to indicate 'do not know,' compared to men. Second, the rate of 'do not know' responses among women decreased substantially when the first set of wordings was used. This is evident both from the lower significance levels of the chi-squared tests performed on the First Wording group in Table 4A, as well as from the strongly negative coefficient on the female and first wording interaction 
term in Table 4B. From these two facts, we conclude that women are more susceptible to framing effects and are also much more likely to respond 'do not know' when such confusion arises. While this is somewhat puzzling, it appears to be consistent with international evidence. For instance, Lusardi and Mitchell (2011c) show that in countries as different as Sweden, Italy, Germany, New Zealand or Russia, women tended to respond in the same way, i.e., they were disproportionately more likely to indicate they did not know the answers to financial literacy questions. Because of such lack of confidence, or perhaps due to true lack of knowledge, women may have become sensitive to how the question is framed; this might have prompted them to respond in a manner that depended on the question wording.

Tables $4 A$ and $B$ here

\section{Conclusion and Discussion}

This paper documents a rather striking lack of financial sophistication among the older population. The extensive HRS module we have examined shows who knows what about capital markets and risk diversification as well as fees; we also rate financial savvy and attitudes toward investing. Further, we have exploited differences in question wording to gain insight into whether respondents were guessing or actually knew the answers to the questions posed. In addition, our paper makes a methodological contribution by examining alternative ways to combine answers to financial literacy questions into an overall index, to help identify which particular questions are most valuable in predicting financial literacy.

To sum up results, we found that people do not have a good grasp of asset pricing, risk diversification, portfolio choice, and investment fees in our HRS sample of respondents age 55 and over-despite having made many financial decisions over their lifetimes, including taking 
our mortgages and loans, made investments, and undertaken retirement accumulation/decumulation decisions. Moreover, we showed that the PRIDIT index is very similar to a measure which simply sums correct answers, so both approaches do a reasonably good job in capturing observed variation in financial literacy. Yet the PRIDIT approach has the advantage of telling us which questions are most informative about overall financial sophistication levels. In our module, the questions related to knowledge of risk diversification, financial savvy, and numeracy were most valuate. In other words, those seeking to measure financial literacy will find it most useful to assess knowledge of these topics.

We also conclude that some groups are consistently found to be significantly less sophisticated about financial matters: women, the least educated, persons over the age of 75, and African-Americans/Hispanics. Women are particularly sensitive to the framing of financial questions when financial terminology is being used. This suggests that more research is needed on the ways in which financial sophistication questions are framed, to evaluate whether and how to help people develop a fuller understanding of how retirement saving and investment work. Moreover, it is useful to develop questions that are gender neutral.

Our findings will be of interest to those seeking to enhance retirement security in the older population. As employees and retirees are increasingly being asked to take on tasks requiring financial sophistication, including making saving, investment, and dissaving decisions pre- and post-retirement, they are likely to do better if they are equipped with more and better financial decision-making tools. One way to do so is to build human capital via educational and retirement planning programs. Nevertheless, a one-size-fits-all approach is unlikely to address saving shortfalls for all the elderly, in view of the very different patterns discerned by sex, age, 
educational levels, and race/ethnicity. Instead, to be effective, targeted programs will better serve people who differ in terms of financial sophistication. 


\section{References}

Behrman, J., Mitchell, O.S., Soo, C. and Bravo, D. (2012) Financial literacy, schooling, and wealth accumulation. American Economic Review P\&P. Forthcoming.

Benartzi, S., Thaler, R.H., Utkus, S.P. and Sunstein, C.R. (2004) Company stock, market rationality, and legal reform. John M. Olin Law and Economics Working Paper No. 218. University of Chicago, Chicago, IL, USA, July.

Brockett, P., Derrig, R.A., Golden, L.L., Levine, A. and Alpert, M. (2002) Fraud classification using principal component analysis of RIDITs. Journal of Risk and Insurance, 69, 341371.

Campbell, J. (2006) Household finance, Journal of Finance, 61, 1553-1604.

Choi, J., Laibson, D. and Madrian, B. (2010) Why does the law of one price fail? An experiment on index mutual fund, Review of Financial Studies, 23, 1405-1432.

Christelis, D., Jappelli, T. and Padula, M. (2010) Cognitive abilities and portfolio choice. European Economic Review, 54, 18-39.

Hastings, J. and Mitchell, O.S. (2011) How financial literacy and impatience shape retirement wealth and investment behaviors. NBER Working Paper No. 16740.

Hastings, J. and Tejeda-Ashton, L. (2008) Financial literacy, information, and demand elasticity: Survey and experimental evidence from Mexico. NBER Working Paper No. 14538.

Hilgert, M., Hogarth, J. and Beverly, S. (2003) Household financial management: The connection between knowledge and behavior, Federal Reserve Bulletin, 309-332.

Kimball, M. and Shumway, T. (2006) Investor sophistication and the participation, home bias, diversification, and employer stock puzzle. University of Michigan Working Paper.

Lusardi, A. (2009) U.S. household savings behavior: The role of financial literacy, information and financial education programs. In Policymaking Insights from Behavioral Economics (ed. by C. Foote, L. Goette, and S. Meier), pp. 109-149. Federal Reserve Bank of Boston, Boston, MA, USA.

Lusardi, A. (2011) Americans’ financial capability. NBER Working Paper No. 17103.

Lusardi, A. and Mitchell, O.S. (2007) Baby boomer retirement security: The role of planning, financial literacy, and housing wealth, Journal of Monetary Economics, 54, 205-224.

Lusardi, A. and Mitchell, O.S. (2008) Planning and financial literacy: How do women fare? American Economic Review P\&P, May, 413-417. 
Lusardi, A. and Mitchell, O.S. (2009) How ordinary consumers make complex economic decisions: Financial literacy and retirement readiness. NBER Working Paper No. 15350.

Lusardi, A. and Mitchell, O.S. (2011a) The outlook for financial literacy. In Financial Literacy: Implications for Retirement Security and the Financial Marketplace (ed. by O.S. Mitchell and A. Lusardi), pp. 1-16. Oxford University Press, Oxford, UK.

Lusardi, A. and Mitchell, O.S. (2011b) Financial literacy and planning: Implications for retirement wellbeing. In Financial Literacy: Implications for Retirement Security and the Financial Marketplace (ed. by O.S. Mitchell and A. Lusardi), pp. 17-49. Oxford University Press, Oxford, UK.

Lusardi, A. and Mitchell, O.S. (2011c) Financial literacy around the world: An overview. Journal of Pension Economics and Finance, 10(4), 497-508

Lusardi, A. and Mitchell, O.S. (2011d) Financial literacy and retirement planning in the United States. Journal of Pension Economics and Finance, 10(4), 509-525.

Lusardi, A., Mitchell, O.S. and Curto, V. (2010) Financial literacy among the young. Journal of Consumer Affairs, 44, 358-380.

Lusardi, A. and Tufano, P. 2009a. Debt literacy, financial experience, and overindebtedness, NBER Working Paper No. 14808.

Lusardi, A. and Tufano, P. (2009b) Teach workers about the peril of debt. Harvard Business Review, November, 22-24.

Mitchell, O. S., Todd, P. and Bravo, D. (2008) Learning from the Chilean experience: The determinants of pension switching. In Overcoming the Saving Slump: Making Financial Education and Saving Programs More Effective (ed. by A. Lusardi), pp. 301-323. University of Chicago Press, Chicago, IL.

Moore, D. (2003) Survey of Financial Literacy in Washington State: Knowledge, Behavior, Attitudes, and Experiences. Technical Report No. 03-39, Social and Economic Sciences Research Center, Washington State University, Pullman, WA, USA.

Ruffino, D. (2011) Resuscitating businessman risk a rationale for familiarity-based portfolios. Available at SSRN: http://ssrn.com/abstract=1013342.

Smith, B. and Stewart, F. (2008) Learning from the experience of OECD countries: Lessons for policy, programs and evaluations. In Overcoming the Saving Slump: How to Increase the Effectiveness of Financial Education and Saving Programs (ed. by A. Lusardi), pp. 345367. University of Chicago Press, Chicago, IL, USA.

van Rooij, M., Lusardi, A. and Alessie, R. (2011) Financial literacy and stock market participation. Journal of Financial Economics, 101, 449-472. 
Yoong, J. (2011) Financial illiteracy and stock market participation: Evidence from the RAND American Life Panel. In Financial Literacy: Implications for Retirement Security and the Financial Marketplace (ed. by O.S. Mitchell and A. Lusardi), pp. 76-100. Oxford University Press, Oxford, UK. 
Figure 1: Question Weights Used to Generate the PRIDIT Index of Financial Sophistication

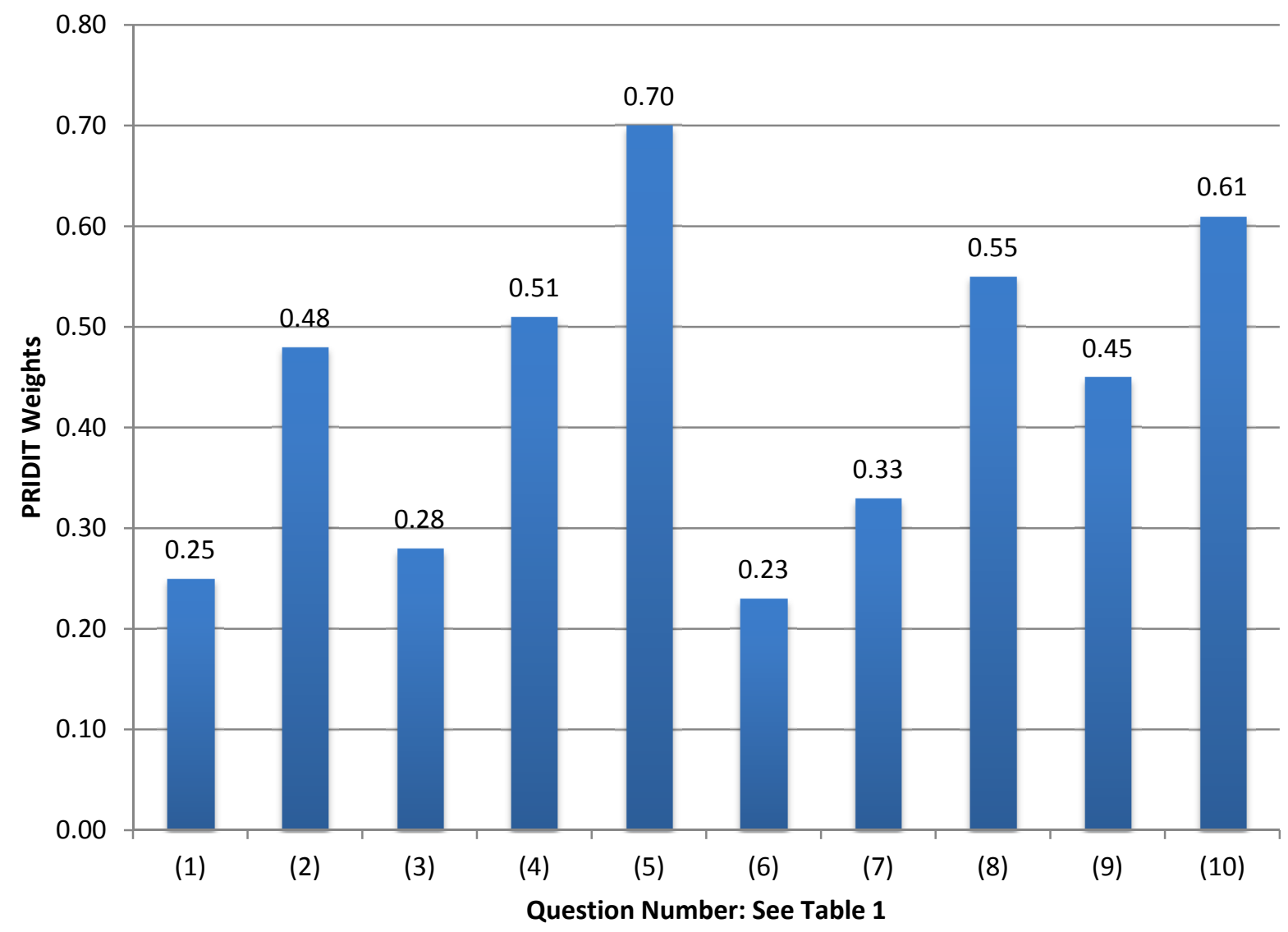

Source: Authors' computations; see text. 


\section{Table 1: Financial Sophistication Questions: Percent Correct}

Knowledge of capital markets

An employee of a company with publicly traded stock should have [a lot/little or none] of his or her retirement savings in the company's stock.

If the interest rate falls, bond prices will [rise/fall].

[If/Even if] you are smart, it is [easy/hard] to pick individual company stocks that will have better than average returns.

\section{Risk diversification}

You should invest [most of your money in a few good stocks that you select rather than in lots of stocks or in mutual funds/in either mutual funds or a large number of different stocks instead of just a few stocks].

When an investor spreads money between 20 stocks, rather than 2, the risk of losing a lot money [decreases/increases].

Knowledge of fees

If you invest for the long run, the annual fees of mutual funds are [unimportant/important].

It is [hard/easy] to find mutual funds that have annual fees of less than one percent of assets.

Savvy/numeracy

To make money in the stock market, you [should not/have to] buy and sell stocks [too/ ] often.

Using money in a bank savings account to pay off credit card debt is usually a [good/bad] idea.

If you start out with $\$ 1,000$ and earn an average return of $10 \%$ per year for 30 years, after compounding, the initial $\$ 1,000$ will have grown to [more/less] than $\$ 6,000$.

Source: Authors’ computations; see text.

\begin{tabular}{|c|c|c|c|}
\hline & $1 \mathrm{st}$ & 2nd & Chi-squar \\
\hline$\underline{\text { Pooled }}$ & Wording & $\underline{\text { Wording }}$ & p-value \\
\hline 51.9 & 72.2 & 33.2 & 0.00 \\
\hline 40.0 & 44.7 & 35.7 & 0.00 \\
\hline 56.4 & 37.6 & 73.7 & 0.00 \\
\hline 64.9 & 60.3 & 69.1 & 0.00 \\
\hline 61.0 & 61.4 & 60.6 & 0.93 \\
\hline 65.7 & 59.9 & 71.0 & 0.00 \\
\hline 39.4 & 42.7 & 36.3 & 0.02 \\
\hline 62.9 & 62.3 & 63.3 & 0.98 \\
\hline 58.3 & 59.8 & 57.0 & 0.07 \\
\hline 61.8 & 70.2 & 54.0 & 0.00 \\
\hline
\end{tabular}

1st 2nd Chi-squares 
Table 2. Simple Financial Sophistication Index: Multivariate Regression Models

\begin{tabular}{|c|c|c|c|c|c|c|c|c|}
\hline & (1) & (2) & (3) & (4) & (5) & (6) & (7) & $(7)$ \\
\hline \multirow[t]{2}{*}{ Female } & $-0.058 * *$ & & & & $-0.047^{* *}$ & $-0.049 * *$ & $-[0.084 * *$ & $0.069 * *$ \\
\hline & $(0.014)$ & & & & $(0.013)$ & $(0.013)$ & $(0.019)$ & $(0.025)$ \\
\hline \multirow{2}{*}{\multicolumn{2}{|c|}{ High School Graduate }} & $0.118^{* *}$ & & & $0.076^{* *}$ & $0.077^{* *}$ & $0.112^{* *}$ & -0.058 \\
\hline & & $(0.019)$ & & & $(0.019)$ & $(0.020)$ & $(0.027)$ & $(0.038)$ \\
\hline \multirow{2}{*}{\multicolumn{2}{|c|}{ College Graduate }} & $0.160^{* *}$ & & & $0.108 * *$ & $0.110^{* * *}$ & $0.121 * *$ & -0.017 \\
\hline & & $(0.021)$ & & & $(0.021)$ & $(0.021)$ & $(0.030)$ & $(0.043)$ \\
\hline \multirow{2}{*}{\multicolumn{2}{|c|}{ Graduate Plus }} & $0.237^{* *}$ & & & $0.176^{* *}$ & $0.178^{* *}$ & $0.151^{* *}$ & 0.065 \\
\hline & & $(0.020)$ & & & $(0.021)$ & $(0.021)$ & $(0.030)$ & $(0.041)$ \\
\hline \multirow{2}{*}{\multicolumn{2}{|c|}{ African Anerican }} & & $-0.139 * *$ & & $-0.116^{* *}$ & $-0.116^{* *}$ & $-0.124^{* *}$ & 0.020 \\
\hline & & & $(0.020)$ & & $(0.021)$ & $(0.020)$ & $(0.030)$ & $(0.041)$ \\
\hline \multirow[t]{2}{*}{ Hispantic } & & & $-0.211^{* *}$ & & $-0.162^{* *}$ & $-0.160 * *$ & $-0.124^{* * *}$ & $-0.091+$ \\
\hline & & & $(0.024)$ & & $(0.026)$ & $(0.026)$ & $(0.034)$ & $(0.050)$ \\
\hline \multirow[t]{2}{*}{ Other Race } & & & -0.023 & & -0.019 & -0.021 & -0.060 & 0.068 \\
\hline & & & $(0.032)$ & & $(0.035)$ & $(0.034)$ & $(0.042)$ & $(0.062)$ \\
\hline \multirow[t]{2}{*}{ Age: $65-74$} & & & & -0.014 & -0.001 & -0.001 & -0.005 & 0.004 \\
\hline & & & & $(0.016)$ & $(0.014)$ & $(0.014)$ & $(0.021)$ & $(0.029)$ \\
\hline \multirow[t]{2}{*}{ Age: $75+$} & & & & $-0.072^{* *}$ & $-0.058 * *$ & $-0.057^{* *}$ & $-0.053^{*}$ & -0.003 \\
\hline & & & & $(0.017)$ & $(0.016)$ & $(0.016)$ & $(0.023)$ & $(0.032)$ \\
\hline \multirow[t]{2}{*}{ First Wording } & & & & & & $0.024+$ & -0.006 & -0.006 \\
\hline & & & & & & $(0.013)$ & $(0.043)$ & $(0.043)$ \\
\hline \multirow[t]{2}{*}{ Constant } & $0.032^{* *}$ & $-0.143^{* *}$ & $0.030 * *$ & $0.020+$ & $-0.037+$ & $-0.050^{*}$ & -0.039 & -0.039 \\
\hline & $(0.010)$ & $(0.015)$ & $(0.008)$ & $(0.011)$ & $(0.022)$ & $(0.023)$ & $(0.030)$ & $(0.030)$ \\
\hline Obs. & 1331 & 1331 & 1331 & 1331 & 1331 & 1331 & 1331 & 1331 \\
\hline R-squared & 0.017 & 0.123 & 0.091 & 0.017 & 0.192 & 0.195 & 0.216 & 0.216 \\
\hline Summaty Statis & Meanı & Mirı & Max & $\mathrm{SD}$ & Obs. & & & \\
\hline Financial Literacy & 0.000 & -0.562 & 0.438 & 0.219 & 1331 & & & \\
\hline
\end{tabular}

Source: Author's computations; see text 
Table 3. PRIDIT Sophistication Index: Multivariate Regression Models

\begin{tabular}{|c|c|c|c|c|c|c|c|c|}
\hline & (1) & (2) & (3) & (4) & (5) & (6) & (7) & $\left(7^{\prime}\right)$ \\
\hline \multirow[t]{2}{*}{ Female } & $-0.008 *$ & & & & $-0.006^{* *}$ & $-0.007 * *$ & $-0.011^{* *}$ & $0.008 * *$ \\
\hline & $(0.002)$ & & & & $(0.001)$ & $(0.001)$ & $(0.002)$ & $(0.003)$ \\
\hline \multirow[t]{2}{*}{ High School Graduate } & & $0.014 * *$ & & & $0.009 * *$ & $0.009 * *$ & $0.014 * *$ & -0.007 \\
\hline & & $(0.002)$ & & & $(0.002)$ & $(0.002)$ & $(0.003)$ & $(0.004)$ \\
\hline \multirow[t]{2}{*}{ College Graduate } & & $0.020 * *$ & & & $0.013^{* *}$ & $0.014^{* *}$ & $0.016^{* *}$ & -0.003 \\
\hline & & $(0.002)$ & & & $(0.002)$ & $(0.002)$ & $(0.004)$ & $(0.005)$ \\
\hline \multirow[t]{2}{*}{ Graduate Plus } & & $0.029 * *$ & & & $0.022^{* *}$ & $0.022 * *$ & $0.020^{* *}$ & 0.005 \\
\hline & & $(0.002)$ & & & $(0.002)$ & $(0.002)$ & $(0.004)$ & $(0.005)$ \\
\hline \multirow[t]{2}{*}{ African American } & & & $-0.018^{*}$ & & $-0.015^{* *}$ & $-0.015^{* *}$ & $-0.016 * *$ & 0.003 \\
\hline & & & $(0.002)$ & & $(0.002)$ & $(0.002)$ & $(0.003)$ & $(0.005)$ \\
\hline \multirow[t]{2}{*}{ Hispanic } & & & $-0.025^{*}$ & & $-0.019 * *$ & $-0.019 * *$ & $-0.016 * *$ & -0.008 \\
\hline & & & $(0.003)$ & & $(0.003)$ & $(0.003)$ & $(0.004)$ & $(0.006)$ \\
\hline \multirow[t]{2}{*}{ Other Race } & & & -0.005 & & -0.004 & -0.005 & $-0.011^{*}$ & 0.011 \\
\hline & & & $(0.004)$ & & $(0.005)$ & $(0.004)$ & $(0.005)$ & $(0.008)$ \\
\hline \multirow[t]{2}{*}{ Age: $65-74$} & & & & -0.002 & -0.001 & -0.001 & -0.001 & 0.000 \\
\hline & & & & $(0.002)$ & $(0.002)$ & $(0.002)$ & $(0.002)$ & $(0.003)$ \\
\hline \multirow[t]{2}{*}{ Age: $75+$} & & & & $-0.009 * *$ & $-0.008 * *$ & $-0.008^{* *}$ & $-0.007 *$ & -0.001 \\
\hline & & & & $(0.002)$ & $(0.002)$ & $(0.002)$ & $(0.003)$ & $(0.004)$ \\
\hline \multirow[t]{2}{*}{ First Wording } & & & & & & $0.003^{*}$ & 0.001 & 0.001 \\
\hline & & & & & & $(0.001)$ & $(0.005)$ & $(0.005)$ \\
\hline \multirow[t]{2}{*}{ Constant } & $0.007^{* *}$ & $*-0.014^{* *}$ & $0.007^{* *}$ & $* 0.006 * *$ & -0.001 & -0.003 & -0.002 & -0.002 \\
\hline & $(0.001)$ & $(0.002)$ & $(0.001)$ & $(0.001)$ & $(0.003)$ & $(0.003)$ & $(0.004)$ & $(0.004)$ \\
\hline Obs. & 1331 & 1331 & 1331 & 1331 & 1331 & 1331 & 1331 & 1331 \\
\hline R-squared & 0.022 & 0.139 & 0.100 & 0.021 & 0.219 & 0.223 & 0.239 & 0.239 \\
\hline Summary & Mean & Min & Max & SD & Obs. & & & \\
\hline PRIDIT: Pooled Sample & 0.003 & -0.058 & 0.050 & 0.026 & 1331 & & & \\
\hline
\end{tabular}

Source: Authors’ calculations; see text. 
Table 4A. Financial Sophistication: Do Not Know Responses by Sex

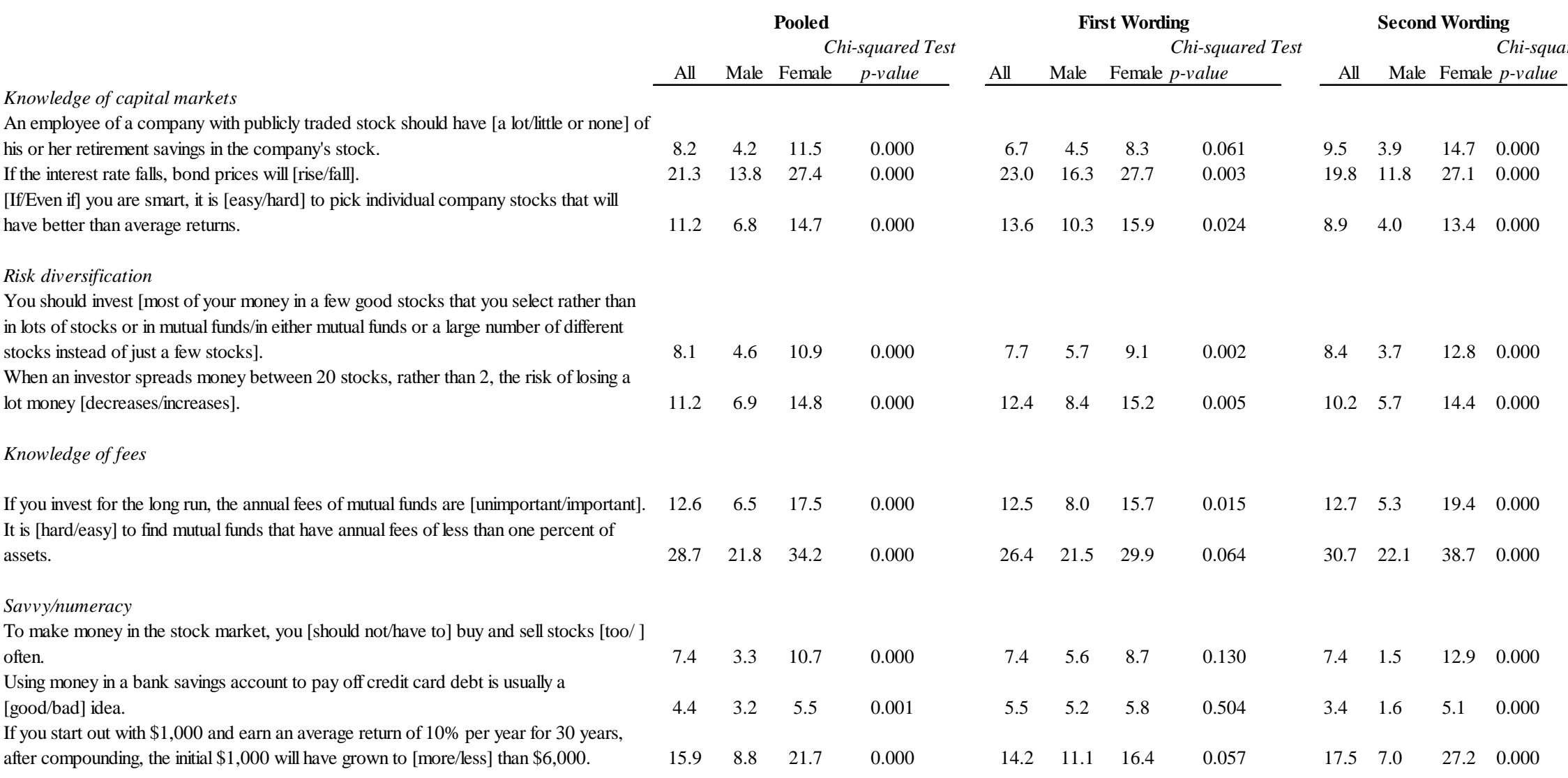

Source: Authors’ computations; see text. 
Table 4B. Financial Sophistication: Do Not Know Responses by Sex

\begin{tabular}{|c|c|c|c|c|c|}
\hline & (1) & (2) & $\left(2^{\prime}\right)$ & & \\
\hline \multirow[t]{2}{*}{ Female } & $0.087 * *$ & $0.124 * *$ & $-0.077 * *$ & & \\
\hline & $(0.013)$ & $(0.018)$ & $(0.025)$ & & \\
\hline \multirow[t]{2}{*}{ High School Graduate } & -0.026 & $-0.065^{*}$ & 0.061 & & \\
\hline & $(0.025)$ & $(0.033)$ & $(0.047)$ & & \\
\hline \multirow[t]{2}{*}{ College Graduate } & $-0.047+$ & $-0.062+$ & 0.023 & & \\
\hline & $(0.024)$ & $(0.032)$ & $(0.047)$ & & \\
\hline \multirow[t]{2}{*}{ Graduate Plus } & $-0.056 *$ & -0.048 & -0.029 & & \\
\hline & $(0.023)$ & $(0.034)$ & $(0.046)$ & & \\
\hline \multirow[t]{2}{*}{ African American } & 0.035 & 0.051 & -0.037 & & \\
\hline & $(0.025)$ & $(0.040)$ & $(0.050)$ & & \\
\hline \multirow[t]{2}{*}{ Hispanic } & $0.120 * *$ & 0.057 & $0.148^{*}$ & & \\
\hline & $(0.038)$ & $(0.039)$ & $(0.073)$ & & \\
\hline \multirow[t]{2}{*}{ Other Race } & $-0.059 *$ & -0.021 & -0.062 & & \\
\hline & $(0.028)$ & $(0.052)$ & $(0.059)$ & & \\
\hline \multirow[t]{2}{*}{ Age: 65-74 } & 0.017 & 0.028 & -0.021 & & \\
\hline & $(0.015)$ & $(0.020)$ & $(0.029)$ & & \\
\hline \multirow[t]{2}{*}{ Age: $75+$} & $0.037^{*}$ & 0.027 & 0.017 & & \\
\hline & $(0.016)$ & $(0.022)$ & $(0.032)$ & & \\
\hline \multirow[t]{2}{*}{ First Wording } & -0.005 & 0.015 & 0.015 & & \\
\hline & $(0.013)$ & $(0.046)$ & $(0.046)$ & & \\
\hline \multirow[t]{2}{*}{ Constant } & -0.034 & -0.037 & -0.037 & & \\
\hline & $(0.025)$ & $(0.033)$ & $(0.033)$ & & \\
\hline Obs. & 1331 & 1331 & 1331 & & \\
\hline R-squared & 0.085 & 0.108 & 0.108 & & \\
\hline Summary Statistics & Mean & Min & Max & SD & Obs. \\
\hline Do Not Know Index & 0.000 & -0.129 & 0.871 & 0.221 & 1331 \\
\hline
\end{tabular}

Source: Authors' computations; see text. 
Appendix.: Descriptive Statistics for the HRS Sample

$\begin{array}{lccccc} & \text { Mean } & \text { Min } & \text { Max } & \text { SD } & \text { Obs. } \\ \text { Female } & 0.551 & 0.000 & 1.000 & 0.498 & 1331 \\ \text { High School Graduate } & 0.324 & 0.000 & 1.000 & 0.468 & 1331 \\ \text { College Graduate } & 0.241 & 0.000 & 1.000 & 0.428 & 1331 \\ \text { Graduate Plus } & 0.281 & 0.000 & 1.000 & 0.450 & 1331 \\ \text { African American } & 0.090 & 0.000 & 1.000 & 0.286 & 1331 \\ \text { Hispanic } & 0.079 & 0.000 & 1.000 & 0.269 & 1331 \\ \text { Other Race } & 0.023 & 0.000 & 1.000 & 0.151 & 1331 \\ \text { Age: 65-74 } & 0.280 & 0.000 & 1.000 & 0.449 & 1331 \\ \text { Age: 75+ } & 0.223 & 0.000 & 1.000 & 0.416 & 1331 \\ \text { Financial Literacy Index } & 0.000 & -0.562 & 0.438 & 0.219 & 1331 \\ \text { PRIDIT: Pooled Sample } & 0.003 & -0.058 & 0.050 & 0.026 & 1331 \\ \text { Do Not Know Index } & 0.000 & -0.129 & 0.871 & 0.221 & 1331\end{array}$

Source: Authors’ computations; see text. 